Enrique Llopis Agelán y Jordi Maluquer de Motes (Eds.). España en crisis. Las grandes depresiones económicas, 1348-2012. Barcelona, Pasado y Presente, 2013, 252 págs., ISBN: 978-84-939863-8-4.

\section{La Historia como inspiración}

En los últimos tiempos, en el ámbito de la Economía, se ha intensificado el recurso a la historia como medio para mejor entender el presente. No debiera suponer sorpresa esta tendencia, pues es bien sabido que la realidad social, aunque cambiante, aparece gobernada por una poderosa inercia. No es extraño, por tanto, que el estudio de la génesis histórica y el recurso a los análisis comparados constituyan 2 vías fecundas para interpretar la realidad más actual.

Pese a esa evidencia, ha de reconocerse que no siempre la Economía ha sabido apreciar el valor del análisis histórico. No es ajeno a ello el afán de la Economía por construir un conocimiento de validez universal, capaz de trascender la singularización que imponen las contingencias del devenir histórico de cada cual. De hecho, la Economía ha tratado de acercar su proceder al de la Física, la más valorada de las ciencias, aquella en la que justamente la historia o no cuenta o tiene una dimensión que excede a la experiencia humana. Que la Economía se erija, además, sobre la gran metáfora del equilibrio (un concepto importado de la mecánica) no ha ayudado a la adecuada integración del tiempo histórico, que por definición comporta una secuencia sucesiva e imprevisible de cambios. Es más, cuando los modelos económicos integran el tiempo, este suele aparecer como una variable formal, equiparable a otras, $y$, como ellas, de naturaleza reversible, dependiendo del signo que se le atribuya. Es un tiempo abstracto que niega la realidad del tiempo histórico, el propio de la experiencia humana que, como sabemos, solo opera en una dirección: desde un pasado inapelable a un futuro abierto a la novedad.

Que se recobre el papel de la historia en el estudio de la Economía es, pues, algo que todos debemos celebrar. Es un proceso que va de la mano del reciente interés de la Economía por temas -como las instituciones-, que solo cabe tratar con una cierta perspectiva histórica. En todo caso, en este recobrado interés por la historia, hay algunas formas de recurrir al pasado que parecen poco útiles, cuando no manifiestamente engañosas. La literatura reciente ofrece 4 modelos singulares de esta inadecuada utilización de la historia.

El primero es aquel que sugiere que solo en la historia se encuentran las claves del presente. Señalar que la realidad económica tiene una marcada path dependence no debiera hacer pensar, sin embargo, que toda búsqueda necesariamente remite a un pasado remoto. No obstante, esta es la visión que sugieren algunos estudios que han hecho de la experiencia colonial (que se remonta en algunos casos a 5 siglos) o de una simplificada clasificación de las tradiciones jurídicas (common law frente a tradición latina) la explicación de la calidad de las instituciones vigentes. Algunos trabajos de Mahoney o La Porta parecieran ir en esta línea. En ellos se produce una monumental "comprensión de la historia" -como señala Austin-, en la que se suspende la capacidad de agencia de individuos y sociedades durante el tránsito que va desde aquel supuesto pasado decisivo al presente.

El segundo modelo que se quiere criticar es aquel que interpreta la historia como una senda obligada de realización de un modelo normativo, al que inapelablemente parecen estar convocadas las sociedades. La historia, en este caso, no es sino el tránsito hacia la consumación de un nuevo imperativo hegeliano. Esta visión determinista está, sin duda, en algunos autores marxistas, pero se puede encontrar también en pensadores del otro extremo del arco ideológico. El publicitado libro de Fukuyama, El fin de la historia, constituye un ejemplo de lo que se dice; como también lo es aquel influyente estudio de Rostow, Las etapas del desarrollo, en el que la sociedad moderna occidental (léase Estados Unidos) aparecía como el marco normativo en que toda sociedad debía reflejarse.

Un tercer modelo igualmente inconveniente es aquel en el que se apela a la historia como una meta-narrativa construida con un muy limitado soporte empírico. Es la historia sin datos históricos, en la que la densidad interpretativa va muy por delante de la capacidad probatoria de los hechos que se manejan. Algunos trabajos de Engerman y Sokoloff podrían sugerir este tipo de manejo de la historia.

Finalmente, el último de los modelos es el de aquellos que entienden la historia como una acumulación de anécdotas al servicio de una tesis establecida. En este caso, se abandona todo propósito de comprender un período y una sociedad, de sumergirse en sus complejidades, para extraer la anécdota que es funcional a la tesis defendida. El último trabajo de Acemoglu y Robinson, Por qué fracasan las naciones, podría ser un ejemplo de esta forma de proceder.

Frente a estos modelos es necesario reivindicar el estudio de la historia en su sentido pleno, entendido como un proceso de inmersión en una realidad temporal compleja en la que el historiador revela su familiaridad con el contexto, con el tiempo, el lugar y las circunstancias, para tratar de entender lo sucedido y lo que no sucedió. Como apunta Elliott en Haciendo historia, "si el estudio del pasado tiene algún valor, este reside en su capacidad tanto de revelar complejidades de la experiencia humana como de advertir contra la opción de descartar como si no tuvieran ninguna importancia los senderos que se siguieron solo en parte o no se tomaron nunca».

El libro que ahora se presenta cabe enmarcarlo en ese esfuerzo renovado por convocar a la historia para ayudar a entender el presente. Dada la severidad de la crisis económica, todos estamos convocados a buscar las causas que nos han traído hasta aquí y a indagar las vías para erigir un futuro deseable. Que un grupo de reputados historiadores nos ofrezcan lo que mejor conocen, que son las enseñanzas del pasado, como insumos para interpretar el presente, parece un expresión de compromiso y responsabilidad que, cuando menos, debe agradecerse.

Pero, además, en este caso, los autores huyen de esos modelos espurios de utilización de la historia a los que se ha aludido. Ofrecen interpretaciones ricas y complejas de cada uno de los episodios analizados, pero entienden -con refrescante modestia- que no es a los historiadores a quienes corresponde interpretar el presente. La historia puede sugerir, trasladar experiencias útiles, pero la interpretación del presente requiere de más elementos que los que la historia aporta. Practican, además, una historia que descansa sobre una cuidadosa interpretación de datos, en la que los autores se sumergen en el período, al objeto de hacer comprensibles las reacciones y tendencias en juego.

El libro recorre los principales episodios depresivos que padeció la economía española desde 1348 a la actualidad. Pasan por sus páginas la depresión de finales del siglo XIV y principios del XV (Antoni Furió), que el arco mediterráneo compartió con otros países europeos; la larga crisis del siglo XviI (José Antonio Sebastián); la crisis de finales del XVIII y primer tercio del XIX (Enrique Llopis); los efectos de la gran depresión de 1929 sobre España (Francisco Comín); la larga noche de piedra del primer franquismo (Carlos Barciela); la crisis y el ajuste económico que acompañó los primeros años de la transición (Carles Sudriá); y, en fin, la crisis en la que ahora está sumida nuestra economía (Jordi Maluquer de Motes).

La relación de episodios estudiados es suficiente para apreciar las dificultades reiteradas a las que se enfrentó el proceso de modernización de la economía española. Acaso quepa, como apunte crítico, preguntarse por la falta de referencia a la crisis finisecular del siglo XIX, que tantas semejanzas tiene con el momento presente. Es cierto que aquel periodo no tuvo los rasgos propios de una 
depresión, en sentido estricto, pero no es menos cierto que la acumulación de frustraciones, el distanciamiento crítico de la sociedad real respecto de la oficial, la percepción de fin de un modelo que se suponía duradero, tiene mucho de semejanza con cómo la opinión pública percibe la crisis actual.

Cada uno de los episodios críticos tiene sus particularidades, pero son comunes a buena parte de ellos 2 rasgos. En primer lugar, en todas las crisis -quizá con la excepción de los años más negros del franquismo- hay elementos compartidos con el entorno internacional, aunque también elementos específicos. Es decir, España no ha sido tan diferente de su entorno. En segundo lugar, en todos los casos la gestión de las crisis se ha enfrentado a una frágil o ineficiente institucionalidad y a una sociedad altamente fragmentada. Ambos problemas dificultaron la construcción de arreglos institucionales socialmente asumibles, alargando los costes del proceso.

Estos 2 mismos rasgos son característicos también de la crisis actual. Esta coincidencia constituye una demostración del valor que tiene la historia, la buena historia, como inspiración para interpretar el presente.

José Antonio Alonso Rodríguez

Universidad Complutense de Madrid, Madrid, España

http://dx.doi.org/10.1016/j.ihe.2013.11.013

\section{Guillermina del Valle Pavón. Finanzas piadosas y redes de negocios. Los mercaderes de la ciudad de México ante la crisis de Nueva España, 1804-1808. México, Instituto Mora, 2012, 262 págs., ISBN: 978-607-7613-97-8.}

Between 1804 and 1808, the Viceroyalty of New Spain faced an unprecedented fiscal challenge. Under pressure to provide resources to imperial Spain to fight a complex, costly conflict of international scope, Mexico was compelled to transfer about ten percent of its gross domestic product in liquid form to the metropolis. Since about a third of Mexico's national income was claimed by the top twenty percent of families and the cash income of most persons there could have barely exceed 25 cents per day, the expropriation fell squarely on the propertied classes. They did not acquiesce lightly. What Guillermina del Valle has described here is little less the origins of Mexican independence in a debtors' revolt against the Consolidación de Vales Reales (1804-1808), the forced substitution of Spanish debt instruments for liquid colonial assets. Professor del Valle's contribution is threefold: (1) an exhaustive review of the historiography pioneered by Mexican scholars over the past 35 years; (2) her own very considerable and extensive research into the socioeconomic status of the debtors in archives in Spain and Mexico; and (3) a closely drawn analysis of the extended kin groups from which these debtors were recruited, a tightly integrated, closely knit body of actors arrayed across the principal sectors of the economy of central Mexico - planters, merchants, miners, ranchers, agriculturalists and royal officials - the heart of Mexico's political nation - whose interests were most profoundly affected and whose very survival as a class was, in some sense, at stake. While del Valle stands clearly in the debt of other scholars such as Gisela von Wobeser who have done exhaustive research on pious funds, it is in precisely synthesizing such previous work and wedding it to clear network analysis in which her chief, but hardly only accomplishment resides. This will surely remain the standard account of the socioeconomic pressures that led to the overthrow of Viceroy Iturrigaray for years to come. It is a thoroughly professional job.

If there were any more enigmatic, pivotal, and controversial royal official in the early nineteenth century than José de Iturrigaray, who would that person be? He variously stands accused of venality, inflexibility, arrogance, ambition and treachery. By alienating the consulados of Mexico and Veracruz, Iturrigaray virtually signed the warrant for his own demise, for with them came the sugar planters of the hotlands, the cattle and pulque ranchers, and, above all, the vastly indebted landowners of the provinces of Mexico, Michoacán and Puebla, none of whom could manage without the financial capital of the pious funds that Iturrigaray's political masters, such as Manuel Godoy and Cayetano Soler, meant to appropriate. Iturrigaray resisted any and all attempts on the part of opponents to mitigate the workings of the
Consolidación. Indeed, he seems to have gone out of his way to alienate some of the affected, such as Gabriel Yermo, José Martínez Barenque, and Santiago José de Echeverría, who became publicly recognized as coauthors of the conspiracy against him. When the Spanish monarchy collapsed under the weight of foreign invasion in 1808, Iturrigaray, bereft of patronage and support, fell along with it, deposed ingloriously by coup on September 15, 1808 and arrested.

The political divisions behind this dramatic insurgency, supposedly Peninsular and monarchist (Yermo et al.) against Creole and autonomist factions (Iturrigaray, the Ayuntamiento of Mexico and its spokesmen, Juan Francisco de Azcárate and Francisco Primo de Verdad) were clearly far more complex than that, a point that del Valle readily concedes and illustrates. In the wake of the coup, the offending law of Consolidación was immediately nullified, as were a number of other offending fiscal measures. Iturrigaray was replaced by the ineffectual Pedro de Garibay. After the popular insurgency had broken out in 1810, Yermo and a number of his associates were accorded viceregal recognition by Venegas for their efforts, a sort of "reward" as Lucas Alamán had written, for their selfless service to the continuity of colonial rule.

It is, of course, difficult, if not impossible, to make out a definitive interpretation to this confusing welter of events and interests. Even Yermo, the ringleader, and his kinsmen stood on both sides of the issue, some benefitted by the Consolidación, others deeply wounded. Del Valle is persuaded of the eminent, not to say catastrophic unsuitability of Iturrigaray for his position, while other historians - no less qualified or immersed in the sources - have been less categorical. Barbara and Stanley Stein in particular have painted a different picture of Iturrigaray. He was, they think, a capable if conflicted bureaucrat beset by divisions, ethic, economic and political, on all sides, as he attempted to preserve the Empire by enforcing the Consolidación. Mexico was not one of the lesser colonies: its long-standing role as the goose that laid the golden eggs made its noncompliance inconceivable. In their view, this was Iturrigaray's dilemma: support the miners, who provided the sinews of war, or the merchants, who financed the mobilization of capital and invested silver productively. For the moment, it was war or trade. You could not have both. Iturrigaray did what he had to do, and suffered the consequences. The merchants and planters, increasingly committed to an autonomist vision in which they made the decisions that shaped their fortunes, ultimately chose differently. The trick was to find a compromise that would preserve sovereignty, solvency and the legitimacy of the political system, and this, alas, eluded a now-fractured Mexican elite. As del Valle recognizes, the consequences in the nineteenth century were to be catastrophic.

One finds little to dislike in this well constructed monograph. It will serve as an indispensable resource, introduction and 